\title{
The Implementation of Providing Performance Allowance Policy in the Secretariat of the General Election Commission Kota Ternate, Indonesia
}

\author{
Eko Ady Prabowo1, Muhlis Hafel ${ }^{2 *}$, Agus Joko Purwanto ${ }^{3}$, Anfas ${ }^{4 *}$ \\ Universitas Terbuka \\ Email: masbowoberkharisma@gmail.com ${ }^{1}$, muhlis@ecampus.ut.ac.id², ajoko@ecampus.ut.ac.id ${ }^{3}$, \\ anfas_st_mm@ecampus.ut.ac.id ${ }^{4}$
}

(Received: September 1-2019; revised: Oktober 25-2019; published: December 31-2019)

\begin{abstract}
This study aims to evaluate the implementation of the policy of providing performance allowance to employees at the Secretariat of the General Elections Commission (GEC) Kota Ternate, as well as their supporting and obstacle factors. This research is a descriptive qualitative research by using case study. The research data were obtained from informants who were respondents, ranging from staff to officials at the Secretariat of the General Elections Commission Kota Ternate. The results of the study showed that although the implementation of the performance allowance was already running there were still some deviations in its management, namely: 1) no socialization or training was held on the management of performance allowance involving GEC Kota Ternate; 2) there is no appointment of a performance allowance management officer, namely the Performance Allowance Management Officer or the control book Management Officer, therefore, it happens overlap working with routine treasurer; 3 ) there is not a standard operating procedure (SOP) as an assessment standard that aims to provide an assessment and sanctions against employees who do not carry out their duties and functions.
\end{abstract}

Keywords: Implementation, Policy, Allowance, Performance.

\section{INTRODUCTION}

Bureaucratic reform is carried out in the form of organizational structure, working procedures and the determination of performance success measures (Dhaliwal \& Hanna, 2017; Johnsen, 2015; Mathwich \& Pavao-Zuckerman, 2018; Wihantoro, Lowe, Cooper, \& Manochin, 2015). One of the steps to reform the bureaucracy is to carry out improvements to compensation to employees especially in public organizations based on performance. Performance is a process of how the work takes place to achieve work results (Pratiwi, Jamaluddin, Niswaty, \& Salam, 2019; Shet, Patil, \& Chandawarkar, 2019; Wilfahrt, 2018). However, the results of the work itself also show performance (Akib \& Salam, 2016; Pratiwi et al., 2019; Saggaf et al., 2018). Employee performance is one of the most important elements in achieving the goals to be achieved. Employees contribute to good performance in achieving organizational goals, then the organization will also make a good contribution to increase employee morale and enthusiasm, one of which is through performance allowances.

Performance allowance based on the decision of the General Secretary of the Election Commission of Republic of Indonesia No. 935/SDM.07-Kpt/05/SJ/XII/2017 About the Technical Guidelines for Granting Performance allowance in the area of Secretariat General 
138 |Jurnal Ilmiah Ilmu Administrasi Publik: Jurnal Pemikiran dan Penelitian Administrasi Publik Volume 9 Number 2, July- December 2019. Page 137-158

Election Commission is the allowance given to employees as a function of the successful implementation of bureaucratic reform based on class positions and employee performance achievements. Basically, the bureaucratic reform program determines the allowance performance policy as an inseparable part of the bureaucracy reform policy, which is included in the scope of the bureaucratic system structuring. The foundation of allowance performance policy is the awareness and commitment of the government is to realize clean and good governance.

Changes and reforms that are carried out in the context of realizing clean and authoritative governance are unlikely to be carried out properly (effectively) without the proper welfare of the state civil apparatus as executing the government working. These changes and renewals were carried out to erase the impression of a government that had been considered bad. Based on the Minister of Administrative Reform and Bureaucratic Reform Regulation No. 20 in 2010 concerning to Bureaucratic Reform Road Map, states that the performance allowance is a function of the successful implementation of bureaucratic reform on the basis of the performance achieved by an individual employee, which of course must be in line with the performance to be achieved by an institute. In this case, both directly and indirectly, performance allowance is one of the driving factors for improving employee performance, by utilizing and using then maximizing the resources, it is expected to be able to improve optimally performance. Performance allowance is expected to be able to encourage to improve the performance of employees to work opitmally. Performance allowance is expected to encourage to improve the performance of employees to work diligently in accordance with their main job and function.

The implementation of bureaucratic reform within the General Secretariat of the General Election Commission has begun with the sending of proposed documents and road map for bureaucratic reform in the General Secretariat of election commision in 2013. Then continue by forming the Bureaucratic Reform Team which carry out activities according to the road map, until it is done the field verification process by the Ministry of Administrative Reform and Bureaucratic Reform in 2014, therefore it became a requirement for general election commision to receive an award in the form of Performance Allowance which determined through a Presidential Regulation. In 2015 and 2016 evaluation is done again to the implementation of bureaucratic reform within the General Secretariat of general election commision by Ministry of Empowerment of the State Apparatus and Bureaucratic Reform. The result of the assessment was the implementation of bureaucratic reform within the General Secretariat of the General Election Commission which received 66.22 (sixty six point twenty two) so that it was declared eligible to receive an award in the form of $70 \%$ (seventy percent) Performance Allowance increase, marked by the issuance of the Regulation of the President Number 126 in 2017 focus on Employee Performance Allowanc in the Secretariat General Election Commission (State Gazette of the Republic of Indonesia in 2017 Number 270) replace the Presidential Regulation Number 157 in 2015 concerning to employee performance allowance in Secretariat General Election Commission. General Election Commission Kota Ternate is an extension of the general election commisson of Republic of Indonesia that located in the district or city level who has implemented a policy of providing employee performance benefits since 2014 based on the decision of the Secretary General of the election commission RI No.526 / Kpts / Setjen / 
2014 regarding to determination of position rank at the Secretariat General of Election Commission, Provincial Election Commission Secretariat, and district / City Election Commission Secretariat.

The provision of performance benefits is aimed to improving employee welfare and preventing KKN by hoping the employees can work fully responsible. However, based on the results of observations fields there are still some deviations that can be seen in the following table:

Table 1 .

The deviation of Employee Performance Allowance at the election commission Secretariat Kota Ternate

\begin{tabular}{|c|c|c|}
\hline No & Case & Deviasion \\
\hline 1 & $\begin{array}{l}\text { The division of main job and functions through the Decree of } \\
\text { Appointment in the General Functional Position has done but the } \\
\text { implementation of the main jobs and functions are carried out by } \\
\text { different personnel, such as treasurers who have functional position } \\
\text { decree as Salary List Maker but the officer who makes payroll has } \\
\text { a functional position as compiler of Financial Statements. }\end{array}$ & Unproportional \\
\hline 2 & $\begin{array}{l}\text { There is no Decree on the appointment officer of data management } \\
\text { of performance allowance and the officer of managing control } \\
\text { book. }\end{array}$ & Unprofessional \\
\hline 3 & $\begin{array}{l}\text { Circular letter from the Secretary General Number } 5 \text { in } 2016 \\
\text { stipulates the maximum number of employees in the Distric / City } \\
\text { Commission is } 17 \text { people, therefore, it cuses the employes are in } \\
\text { Ternate Election Commission still lack. KPU. }\end{array}$ & Unprofessional \\
\hline 4 & $\begin{array}{l}\text { Recording the employees' attendance do not use electronic } \\
\text { attendance (finger print) as a basis for payment of employee } \\
\text { performance allowance. }\end{array}$ & $\begin{array}{l}\text { Not Transparent, } \\
\text { Accountable, } \\
\text { and Not } \\
\text { Professional }\end{array}$ \\
\hline 5 & The Employees do not make an employee achievement report. & Unprofessional \\
\hline
\end{tabular}

From the table above it can be seen that there are deviations in the management of employee performance allowance and do not meet the elements contained the Decree of the General Commission Secertary of Indonesian No.526 / Kpts / Setjen / 2014 concerning to Determination of Position Rank at the General Secretariat of General Election Commission, Provincial General Elections, and distric/City Election Commission Secretariat. Officials and employees who work in the Secretariat of election commission Kota Ternate in managing employee performance allowance in an effort to implement the policy has not do the main job and functions as what was expected. It can be seen such as: First, the employees are not proportional in working based on their duty and functions. Secondly, there was not decision letter in appointing the Management of data Official for Employee Performance allowance and organizing the management Officials at commession office. Third, Circular letter of General secretary number 5 in 2016 determines the maximum number of employees in the Regency/City is 17 people , therefore the Election Commission Kota Ternate has lack of amployees. Fourth, it 
140 Jurnal Ilmiah Ilmu Administrasi Publik: Jurnal Pemikiran dan Penelitian Administrasi Publik Volume 9 Number 2, July- December 2019. Page 137-158

is not transparent, accountable, and professional because the calculating the payment of employee performance allowance still using the manual system not electronic attendance. Fifth, the employees do not make a report of Employee Performance achievement. Based on this phenomenon, it is interesting to study by referring to amount literature about the standar of the implementation of existing policies, by doing this study it can be known that how far the the implemention of amployees performance allowance policy at the commission, specially in the Secretariat of general Commission Kota Ternate. In addition, researchers also want to know the officials' understanding in secretariat regarding to performance allowance.

\section{METHOD}

This research is a descriptive qualitative research by using case study design. Data collected in the form of words or images rather than numbers. The form of research data such as interview transcripts, field notes and other official notes. The use of qualitative research aimed to obtained the more extensive data and depth so that it can help the research process (Creswell \& Poth, 2018). This research focuses on the implementation of providing employee performance allowance policy in General Election Commission Kota Ternate through Decree of the General Secreraty of Election Commission No. 935 / SDM.07-Kpt / 05 / SJ / XII / 2017 relating to Technical Guidelines for the Implementation of Performance Allowances at General Election Commission Secretariat, as a guideline in organazig the employee performance allowance in General Election commission. There are some indicators are as follows:

1. Communication, delivering the information about a policy should be clear to executors of the policy so that they know what must be done in the policy of employee performance allowance.

2. Resources, consisting of:

a. The quality of human resources, implementers' skills and motivation in implementing policy to organaze the performance allowance.

b. Facilities as a support capacity to implement the providing the employee performance allowance policy.

3. Disposition, these are the characteristics and commitments of the policy implementers in providing employee performance allowance.

4. Bureaucratic structure, in the form of Standard Operating Procedures (SOP) which serves as a guideline for implementing policy practically.

The subjects of the study were 8 (eight) people that consist of: the Secretary of election commission Kota Termate (1person), the head of financial, general and logistics subdivision (1 person), the head of technical Subdivision and public participation relations (1 person), Treasurer (1 person), Secretariat Staffs (2 people), the head of human resourse subdivision Genaral Election commission North Maluku Province (1 person), and the officer of data management of employe Performance allowance in North Maluku Provincial election commission. (1 person). To the determine the subjects of the study the researchers used purposive sampling technique, purposive means the sujects are selected based on particular considerations with previous charateristics which have been known before. The considerations 
namely: first, the subjects must master and understand something through the process of inculturation, therefore something is not only known, but also comprehending fully. Second, the sujects still including a person who actively doing activities which became research problems. Third, the subjects who have sufficient opportunity and time to ask for information. Fourth, the subjects who do not tend to convey the information from their own perspective. Fifth, the subjects were initially quite foreign to researchers so that they were more directed to become a kind of teacher or resource person (Blatt, Bogdan, Biklen, \& Taylor, 1977).

\section{RESULT AND DISCUSSION}

Based on the Presidential Regulation No. 81-2010 referring to the Grand Design of Bureaucracy Reform in 2010-2025, mandates that all ministries / institutions and local governments must do bureaucratic reform. The implementation of bureaucratic reform in General Secretariat of Election Commission has begun with sending of proposed documents and road maps bureaucratic reform in General Secretariat of Election Commission in 2013. Afterwards, it was continued by formating Bureaucratic Reform Team which do the activities beased on road map, until it was done the field verification process by the Ministry of Administrative Reform and Bureaucratic Reform in 2014. Therefore it becames a requirement for General Election Commision to receive an award in the form of Performance Allowance which was determined through a Presidential Regulation. As a preliminary analysis, what was asked for the respondent about the background of existence of a performance allowance policy. respondent "ARH" explains

"Yes, actually tukin that used to be the remuneration is mandated by the law, that civil servants or now ASN must obtain a suitbale salary or income so that finally the Presidential Regulation comes out to regulate that the employees in election commision must also obtain this tukin".

Furthermore, regarding to background of the policy in providing performance allowance itself, "SMS" explains:

"In my observation, Election Commission provides this performance allowance add spirit to the secretariat staffs and support the working in the secretariat. Beside from meal llowance and others, tukin supports and helps to improve the performance"

From this statement it can be seen that the policy of providing performance allowance encourage to improve the performance of employees to work then maximize available resources that are expected to be able to improve optimal performance. Performance allowance is expected to be able to give encouragement to improve the performance of employees to work diligently in based in on their main job and function. Dessler (1999) mention that employee performance is obtained from defining work, namely ensuring that superiors and subordinates agree with their duties and job standards. The Secretariat of Election Commission Kota Ternate, when the first time they received the performance allowance, they had made a devition of class positions and the amount of the value of the performance allowance based on the Decree of the Secretary General of the Election Commission No. 526 / Kpts / Setjen / 2014 about the Position of Designation at the secretariat of General Election Commission , 
142 | Jurnal Ilmiah Ilmu Administrasi Publik: Jurnal Pemikiran dan Penelitian Administrasi Publik Volume 9 Number 2, July- December 2019. Page 137-158

Provincial Election Commission Secretariat, and Regency / City Election Commission Secretariat. Therefore, the employees work in the office based on main job and function respectively. Sopiah (2008) states that the atmosphere can also affect a person's performance. A conducive environmental situation, for example support from leader, patners, facilities and infrastructure will create its own comfort and will spur a good performance. Conversely, an uncomfortable working atmosphere due to inadequate facilities and infrastructure, lack of support from leader, and many conflicts will have a negative impact in deterioration one's performance. The discussion onof he atmosphere in secretatriat genaral Election Commission Kota Ternate will be discussed in the next chapter.

\section{The Implementation of Performance Allowance Policy}

General Election Commission Kota Ternate is as an extension of the General Election Commission of Republic of Indonesia (RI) at the district / city level, they have implemented a policy of granting employee performance since 2014 according to Decision of the Secretary General of the Election Commission RI No.526 / Kpts / Setjen / 2014 based on the determination of level of the position in the Secretariat General of Election Commission, Provincial Election Commission Secretariat, and Distric/ City Election Commission Secretariat. This study using the implementation model of George Edward III , because it is suitable to be implemented at the bureaucratic level structured at General Commission institutions. Each level of the hierarchy has a role in accordance with the duties and functions in eleborating of policy to each bureaucracy with four components of bureaucracy analysis namel; communication, resources, disposition, and a bureaucratic structure.

\section{Communication}

Good communication is one of the determinants of the success of the implementation of the performance allowance policy. The implementation can be achieve the target of policy if the role of decision makers already known what they must do. It can be done if the communication can run well, so that every policy that is implemented can be coordinated in the right section, besides that communication is also related to the policy to be implemented must be accurate and consistent, therefore communication is a very important role and function in a policy. According to Wibowo (2015) communication is the exchange of information between sender and receiver and drawing the conclusions as perceptions about the meaning of something between the individuals involved. Communication in this case concerns to the means or efforts in the process of delivering information. Besides the important of information to support communication, it is also needed the process of transmitting or delivering information, clarity and consistency of information.

\section{a. Transmission (Information Submission Process)}

The process of delivering information referred to in this study is how to deliver information from the policy makers with the implementing parties as well as the targets of the policy, namely the employees at general election commission secretariat Kota Ternate. This is important because the distribution of good communication will be able to produce a good implementation as well. Based on the results of the interview, it was revealed that according to the level of Commission institution, the General Secretary 
of election commission RI as the Budget User Authority (BUA) in issuing policies and rules are actively delivering the policy. The communication developed to each level of election commission institutions has been going well through online media and directly socializing to policy targets. This was revealed by the the respondent "BMIA":

"The first time tukin socialization took place,the socialization was folloewed by the Secretary and the Head of the Data Program and human resources Division. But in WA grop of the human resources devision has, informed the information about tukin and if there is something that we don't understand, we usually discuss it directly through the WA group ".

The same argument was expressed by "SMS" that:

"When talking about communication problems, it is often between the secretary with the head of the sub-division or between the head of the sub-division with the staff under it, and it runs smoothly for the creation of a safe atmosphere, synergized in work. In terms of the tukin problem, the provincail commission has conducted a socialization event once, but I haven't remembered it because it is a long time ago. From the Secretary himself always socializes about the tukin in order to improve the performance of the staff under him ".

From the statement above, it can be seen that the transmission of communication from policy makers to policy implementers has been going well. Delivering a good communication will be able to produce good implementation too. It often happens in the process of implementing communication delivery, namely the existence of miscommunication, so, the policies made will not be conveyed properly when arriving at a certain position.

\section{b. Clarity}

In this research, what it meant by clarity is the content of information both through verbal and nonverbal communication conveyed from policy makers to policy implementers. Regard to clarity of information on communication factors as revealed by the "BMIA" that:

"Submission of socialization is done by the leadership not formally but only informally like hung out together like this. In the past time we had a meeting for the first time but only a few staffs came. The distribution of tukin information through technical guidelines distributed to employees I feel is ineffective because many of staff do not read so it is only getting through verbal."

The same argumentation also stated by "ARH" that:

"The rules are clear because I am also a policy implementer and I also read the rules that explain it. So far, socialization for all matters including staffing has been done by the Election Commision RI and ifinviting the Provincial election Commission. To whole distric/ City KPU is usually done through a circular letter from the General Secretary Genral RI, but in the implementation, the provincial Election as an extension 
144| Jurnal Ilmiah Ilmu Administrasi Publik: Jurnal Pemikiran dan Penelitian Administrasi Publik Volume 9 Number 2, July- December 2019. Page 137-158

of commission RI.. very much.. it still very poor in order to conduct employee coaching in the form of socialization to districts/cities it's still very lack. "

Based on the explanation from respondents, it can be concluded that the clarity of information for policy implementers so far is good and very clear, but in its implementation there are still shortcomings. This is due to the unwillingness of the policy implementers to understand the policies that serve as a guideline and become a reference in the implementation of the performance allowance policy and there is no knowledge delivery in terms of managing performance allowanve from the North Maluku Provincial Commission to the Ternate Election Commission. This is as revealed by the respondent "NA"

"If tukin information is in the office ... if I am not mistaken, it was ever socialized in the form of a meeting, soit was deliverd the information about the tukin. If it's from the Provincial Commission or from the Central Commission I think it hasn't. so we only refer to the existing from technical guidelines "

The explanation from respondent above, it can be concluded that the information conveyed by policy makers to the implementers of the policy has been done properly, which refers to the technical guidelines for the provision of performance allowance delivered by the Central Commission However, in its implementation, according to the level North Maluku Province institution never done any socialization to commission from distric/city.

\section{c. Consistent}

The Implementation must be consistent, clear and clean so that the policy can run effectively. Information is clear and clean, but instructions/command are contrary to information received, so it will be difficult to implement the policy easily on operations to accelerate implementation. However, the implementers are sometimes charged with conflicting or unsuitable information. The socialization of providing performance allowance policy in Election Commission Secretariat has gone well through formal and informal communication as stated by respondent "ARH" as follow:

"Related to the tukin policy, it is done formally and informally. So it was conveyed in a meeting regarding to tukin information. "

When it was confirmed respondent "BMIA" he also conveyed the same argument namely:

"The socialization is done by the leadership both formally but also informally, just like chatting together like this. If it was the first time we had a meeting but only a few staffs came"

Communication is the most effective thing in an effort to change a person's attitude, opinion or behavior, because it is dialogic in the form of conversation. The reverse flow is direct, and the communicator knows the communication response right then and there during the communication. In managing performance allowance, 
communication of every official must be carried out, in oder that the process of supervision and control and evaluation can proceed, so, the implementation of the performance allowance can gain well. Supervision and control is the responsibility of the head of the office of the Ternate KPU Secretariat working unit, the Secretary. Supervision and control in managing performance allowance can be in the form of supervision conducted by leader to employee. Based on observations, the Secretary of the Ternate Election Commission has conducted direct supervision and control of the employees. This is stated by respondent "SMS":

"When talking about the problem of supervision we are very grateful to our current leader because he always reminds us about tukin was given not for free but to increase enthusiasm as I said earlier as a vitamin to increase we have the stamina for us to work so tukin it was not given in vain .. "

The same command stated by respondent "HN"

"... besides the lack of tukin because of the consequences of being late or not entering the office ... there is also a reprimand from the leader"

The effectiveness of work relationship in an organization will be realized by intense communication. This was proven by Febriyana, et al (2015) in their research, to achieve or realize the implementation of the job properly and optimally, communication between individuals and groups is absolutely necessary, especially communication that is built with specific goals for institutional interests. Communication that was built by employees in the area of Ternate Election Commission has been going well, itis proved as by respondent SMS' statament as follow:

" When talking about communication problems, it is very often between the secretary with the head of the division and between the head of the sub-division with the staff under it, and it runs smoothly for the creation of a safe atmosphere, synergized in working"

Communication process is very important in human life, as well as in the life of an organization. In the practice of organizational life, communication activities are very complex which involves all elements in the organization, of course all members in organization have a high degree of heterogeneity or diversity so the possibility of homogeneity in organizations is almost not existent. Effective communication within an organization can occur between leaders and staffs or vice versa between staffs and leaders and between staffs and staffs. An agency or organization needed a system that can support performance, one of that is organizational communication. Implementing a good performance allowance policy will show the level of performance produced by the government organization. Organizational communication is a part that must be present if the activities/work processes want to run smoothly. Good organizational communication, organizational goals can be achieved based on the planning. In organizational life the achievement of goals with all its processes requires good communication. Organizational members absolutely need to communicate with each other. Good communication in implementing policies make what will be done clearly 
146 Jurnal Ilmiah Ilmu Administrasi Publik: Jurnal Pemikiran dan Penelitian Administrasi Publik Volume 9 Number 2, July- December 2019. Page 137-158

and directed. Every policy submitted by the leadership will be clearly and understood by the employees in doing their duties.

\section{Resources}

According to Edward III in Mulyadi (2016) implementation is a policy process that can be implemented easily. In doing so, it requires conditions including people or executors, money and organizational competance. The important aspects that need to be considered in the resource factor in policy implementation are related to the number of staff, information, authority (authority), and facilities (facilities) as a support for implementing the policies, which include the availability of buildings, equipment, and supplies as well as employee training and development facilities.

\section{a. Staff (human resources)}

Resources that support or hinder the implementation of policies in the management of performance allowances at Ternate Election Commission Secretariat related to understanding of human resources and facilities and infrastructure, the success of an organization is strongly influenced by the quality of Human Resources (HR) . Human Resources (HR) will be good quality and its performance if it is led and managed properly. Every leader and manager as well as the part that handles HR must understand and appreciate HR management issues as well. Determine the needs of human resources in an organization, especially those related to its quality, the organization must first of all know to recognize and understand the goals, structure, functions and jobs that exist in the organization. Likewise, to be able to create the right supervision, namely placing the right person in the right position, every position in the organization must know the details of what tasks are needed and what personal requirements are required by that position. As the results of observations and interviews with respondent, related to the knowledge of human resources is still very lack so that the impact on the process of managing performance allowances cannot run optimally. Based on General Election Commission Regulation Number 2 in 2012 Concerning to Career Patterns of Civil Servants in the Secretariat General Election Commission, Provincial Election Commission Secretariat, and Regency / City Election Commission Secretariat in filling structural positions within Certral Commission, Provincial Commission, and Distric/City aboau the officials who occupy structural positions, the Secretary of Ternate Commission forms Departement Consideration Team for Secretariat to examine proposals for appointment or dismissal or mutation of positions in Ternate Secretariat Commission. One of the requirements to occupy this position is to have expertise, knowledge and experience in accordance with the field of duty for the position to be occupied. However, the phenomenon that occur in the implementation of the performance allowance policy at the Ternate Election Commission Secretariat besed on obervation and results revealed that in the placement of officials at Ternate Commission Secretariat, the Ternate Commission did not form a Position and Rank Advisory Board Team and they did not consider the requirements as stipulated in the provisions referred to. The proposed placement of positions is only based on the Decree of the North Maluku Provincial Commission Secretary after being proposed from the 
Ternate Commission Secretary. This was revealed from the results of the interview with respondent"BMIA" :

"... at the Commission here, when the placement of employees does not consider skills and background then experience, but only based on rank, closeness, and tolerance."

Recruitment or procurement of personnel is an activity to attract qualified personnel based on what is needed by the organization. Personnel needs include the number and expertise to be recruited adjusted to Human Resource Devision plan that has been determined. The importance of placing officials in filling positions with regarding to educational background and taking into account existing skills is very supportive of what will be done by these officials. Based on observations, the executor of the performance allowance policy does not understand and carry out the HR plan that has been set in the technical instructions contained in the Decree of the Secretary General of the General Election Commission No. 935 / SDM.07-Kpt / 05 / SJ / XII / 2017 Regarding to the Technical Guidelines for the Implementation of Performance Allowance at the General Election Commission Secretariat. In the technical guidelines, the Commission from Distric/City KPU must through a dicision letter to appoint attendance management officials consisting of: First, Performance Allowance Data Managers, namely officials at the Distric/City Secretariat who handle staffing, tasked with managing the performance allowance data at Commission in Distric/City. Second, the Control Book Manager is the official at Commission in Distric/City Secretariat whose job is to manage the control book including recording and verifying the attendance and absence of employees in each work unit. However, based on observations, Ternate Commission Secretariat did not have a presence management official. The attendance recapitulation is only carried out by a staff member in the Finance, General and Logistics Subdivisions. This was revealed from the results of the following interview with "NA":

"To manage tukin I myself records the attendance after that I give to to finance devision, so l finance will process until payment, I only record the attendance results every month. For the manager's decree, there isn't any ... "

When confirmed to Respondent "ARH" She also conveyed the same statment:

"Well ... that is the requairment, there must be an official then in the decree, but the decree if not mistaken, there is no honorarium, so the decree is not made haha ... (laughs). Now this must be reviewed so that the operator of the official manager of tukin has an existing position and can be likened to a financial manager, archive management, then an inventory of BMN and so on "

Similar information was also conveyed by respondent "HN" as follows:

"Until now there is no tukin payment manager... there is no Decree because the workload is given especially since they are in the public section so it is their duty to recap attandance so the decree does not need to be made ... we are also in terms of limited human resourses. " 
148 | Jurnal Ilmiah Ilmu Administrasi Publik: Jurnal Pemikiran dan Penelitian Administrasi Publik Volume 9 Number 2, July- December 2019. Page 137-158

Based on the explanation from the respondent above, it can be concluded that in the implementation of the policy, officials do not understand what are the aims and objectives of the Human Resources planning that have been set in the policy, thus causing the implementation of the policy to deviate from the initial goal.

\section{b. Information}

Information relating to how the policy is implemented is one of the indicators in the resources who must be known by the policy implementer. The implementers need to know what is done and how they should do it. Thus, the implementers of the policy must be given instructions to implement the policy. General Commission RI as a policy maker has published technical guidelines for the implementation of performance allowance from the Central Commission to the Distric /City Commission. However, in conveying that information Commission RI socialized the technical guidelines only facilitating the Provincial Commission level and does not invite the Commission from Distric / City KPU, therefore the information obtained from the Ternate General Commmission is only learning from the technical instructions published by Commission RI. This statament supported by "ARH" commands as follow:

" so far the socialization so for everything including staff is done by the Central Commission RI then inviting the Provincial Commission. Nah as a whole until the Commission in the Distric / City is usually done through a circular letter from the General Secretary of Commission RI, but in the implementation, the provincial Commission as an extension of Commission RI still very poor in order to conduct employee coaching in the form of socialization to districts / cities ...

\section{c. Authority}

Implementing officials or implementors are the factors that determine whether a policy is difficult or not implemented. Commitment to behave based on the important policy goal is held by implementing officials. Therefore sufficient authority is needed which is the authority or legitimacy for policy makers such as the development of clear rules, effective monitoring and control then transparent in implementing policy so to prevent the possibility of official behavior that is contrary to the goals. Based on observations, the authority of the policy maker in providing performance allowance is Central Commission RI in terms of the authority of monitoring and control has not been running optimally. It causes that up to now there has not been regular supervision and control and tiered to all levels of commission below it, therefore control function in the implementation of the granting policy performance allowance is still weak. This was also revealed from the results of interviews with respondent "DD"

"Supervision ... in my opinion the supervision of tukin has not yet been established until now from the policymaker ... Commission RI ... until now I also see that no inspectorate come down to audit tukin. ... only if we are late or do not enter the office we will usually be immediately deducted by the funds. " 


\section{d. Facilities}

According to Widodo (2014) training and development are all efforts made to improve employee performance through enhancing their abilities and knowledge by attending training or learning. Training and learning facilities here involve formal and non-formal education both owned by the employees especially the officials managing the performance allowance. The limited understanding of human resources in managing work in the office needs to be addressed by reevaluating officials who have technical competence, can use office equipment properly (e.g computers) whose recruitment through selection of due diligence and proper test, pay attention to employee backgrounds, and provide good training formal or informal for employees. From the results of the interview with the respondent "NA" it was faund that so far there is never any training provided either from the North Maluku Provincial commission or the Central Commission RI regarding to the management of performance allowance. The following statement below:

"for tukin itself, there has not been any special training so far ... so in the management of tukin, yeah ... we learn by ourselves ... just read the rules"

The same statement was stated by respondent"ARH" as follow:

"So far, socialization or training for everything including staffing has been done by the Central Commission and inviting the Provincial Commission. Nah to all Commission from Distric/City is usually done through a circular letter from the General Secretary of Central Commission, but in the implementation the provincial Commssion as an extension of Commission RI ee....it is still very poor in order to conduct employee coaching in the form of socialization to commission in districts/cities "

From the above explanation it can be concluded that performance allowance management official never participated in training facilities regarding to performance allowance because indeed both the North Maluku Provincial Commission and Central Commission have never been invited the performance allowance management officials at the Ternate Election Commission level to participate in the training. In addition, the employee training and development facilities, there are several facilities to support the implementation of policy, which include the availability of buildings, equipment, and supplies. Based on observations, Ternate Election Commission has already office building located on Jalan Kalumata Puncak No. 2 South Ternate, with office equipment and supplies such as tables and chairs, computers and so on to support the implementation of the main jobs and functions of the employees.

\section{Disposition}

The third factor analyzed in this study is disposition, namely the occurrence of trends concerning to the impact of disposition, staff bureaucracy, namely the appointment of bureaucrat. Every policy implementation instructed by the leader through communicative, persuasive instructions and the behavior of the administrator, accepts the implementation of the policy or program well. Implementation of the policy is very possible for the disposition 
150 | Jurnal Ilmiah Ilmu Administrasi Publik: Jurnal Pemikiran dan Penelitian Administrasi Publik Volume 9 Number 2, July- December 2019. Page 137-158

of the implementer, obstructing the implementation of the policy if the implementor does not agree with the substance of the policy they must carry out. In case of disposition or attitude is found a good response from the implementor. Implementors still do according to their respective duties and functions although there are still shortcomings and limitations such as overlapping positions. This was revealed from the results of interviews with respondent "NA" namely:

"Regarding to the policy of providing my performance allowances ... yes ... I have to be responsible do the work even though the work is a lot because it has already been paid for."

Regarding to overlapping positions or concurrent positions, this was revealed by repondent "CNR" namely:

"If in a functional position, yes ... or in this tukin I am a Salary List Builder, but in reality I was appointed as treasurer by the Budget User Authority, that is the Secretary, well, what I do is also the work of the treasurer, then to make a salary list there are also other financial management staff but his own position is as a Compiler of Financial report."

Additional information about overlapping positions or double positions, the "CNR" stated that:

"I don't know either. But from the Commission's technical guidelines governing Tukin there is also no treasury position so I can't help but I accept it when I get a functional position decree as a Salary List Maker. At that time, I had asked the Provincial Commission, but they were also the same, he said, throughout North Maluku and nationally, there had not been a treasury position for a while. So like it or not, it has to be done, yeah, what does this include ..."

The implementation of performance allowance policy at the General Election Commission Secretariat relation to the disposition aspects, as a result of observations and interviews with number of responend that in the implementation of performance allowance management all processes start from recording the attendent list done by e General Subdivision and the counting process until the payment is made at the Sub Division Finance. The Secretary of Ternate Election Commission in his authority has never made a Secretary's Decree to appoint officials of performance allowance management officers, both the Performance Allowance Data Management Officer and the Management Book but only instructing a senior high school graduate staff to be in the general subdivision to assist the treasurer to record the employee attandent list. In implementing this performance allowance policy, the Secretary of the Ternate Election Commission did not describe the commitment contained in the technical guidelines for managing performance allowance. This is reflected in every request for disbursement of employee performance allowance which should go through the officials managing the performance allowance precisely to the treasury desk without going through a process that is ideally carried out. Commitment is a person's willingness to improve themselves and show loyalty to the organization because they feel themselves involved in organizational activities. Organizational commitment is outside the 
manager's control and thus provides little opportunity to improve feelings. Commitment tends to decrease when there are many job opportunities (Wibowo, 2015).

\section{Bureaucratic Structure}

Bureaucracy has an important role in policy implementation even though it is a large and complex organization, a dominant organization capable of implementing every policy or program, and there is not organization as strong as a bureaucracy is able to survive in any situation, however external influences. Bureaucratic structure factor found in management of performance allowance Ternate Election Commission includes several aspects, especially Standard Operating Procedure (SOP) and sanctions imposed to employeea who have an impact to the coordination and motivation of employees in doing their duties and functions. This dimension has an impact on policy implementation in the sense that policy implementation will not succeed if there are weaknesses in the bureaucratic structure. Problems related to bureaucratic structure can be seen from the position of each employee in carrying out their work. There is no Standard Operating Procedure (SOP), sanctions, and lack of supervision conducted by inspectorate which has oversight functions to staff, finance, and equipment as well as the implementation of election operational activities at the Provincial Commission and Distric/City Commission . it can be supported by the statement of respondent "ARH"

"The Certraal Commission, the Provincial Commission, and the Ternate Commission have not yet established SOP, the process of managing employee performance allowance just refers to the Minister of Finance regarding to it. the procedures for payment of the performance allowance or the tukin also referring to the Commission RI Decree on the Technical Guidelines to the Implementation of Performance Allowance at the General Secretariat of the Election Commission "

The management of performance allowance needs to be put in order with control, both internally and externally. At Ternate Election Commission, supervisory function is attached to the element of Commission Secretary appointed by the head e of Ternate Commission. In process of supervision and control, Secretary of Commission never supervised the implementation of policy in the management of performance allowance. The General Secretary has delegated the authority of the Budget User Authority (BUA) to the Provincial Commission and Districs/City KPU Secretary whose aim to minimize problems that could hinder the process of implementing the policy of providing performance allowance to each work unit. However, in its implementation, the Commission Secretary did not understand his duties and responsibilities as a BUA. This was revealed from the results of interview with respondent "ARH"

"Now there is operator, as manager if attendance list for the tukin itself but the form of supervision is still using the SKP itself. Incidentally, tukin punishment itself is only not paid but the punishment itself has implications to PP 53 regarding to employee discipline that has been set there. Based on the reward or award it must also be considered" 
152 | Jurnal Ilmiah Ilmu Administrasi Publik: Jurnal Pemikiran dan Penelitian Administrasi Publik Volume 9 Number 2, July- December 2019. Page 137-158

The implementation of the policy on the provision of performance allowance is done to avoid deviation in the management of performance allowance and to realize an increase the employee performance in implementing bureaucratic reform based on the basic rules stipulated in constituation Number 43 in 1999 and Presidential Regulation Number 126 of 2017 which is followed up by a Decree of the Secretary General Election Commission Number 935 / SDM.07-Kpt / 05 / SJ / XII / 2017 regulates the management of performance allowance. The policy of implementation is done through employees to cooperate with each other structurally depicted in the organizational structure of government. The organizational structure performs various functions which are part of the division of work and the rational organization requires systemic division of work, rights, and power.

\section{Factors Supporting the Implementation of the Performance Allowance Policy}

There are several factors that support the implementation of providing performance allowance policy to the Ternate Commission Secretariat, including:

\section{Increasing performance allowances}

In 2015 and 2016, it is done an evaluation of the implementation of bureaucratic reform within Secretariat General by the Ministry of Empowerment of the State Apparatus and Bureaucratic Reform. The results of the assessment of implementation of bureaucratic reform within the General Secretariat Election Commission received a value is 66.22 (sixty six point twenty two) so it was declared eligible to receive an award in the form of $70 \%$ (seventy percent). Performance Allowance increase from the original is 60\% (sixty percent), this increase is marked by publishing th of Presidential Regulation Number 126 in 2017 regarding to Employee Performance Allowance in the General Secretariat Election Commission (State Gazette of the Republic of Indonesia in 2017 Number 270) replaces Presidential Regulation Number 157 in 2015 concerning to Employee Performance Allowance in General Secretariat of the Election Commission. The increasing of performance allowance is one of a good news for all Commission employees because it can improve enthusiasm for working and it will improve their performance. This is supported by statement from respondent"SMS" below:

"Thank God, until now the employees are very thankful because they feel helped because we now that 99 percent Sevil Sevent letter of dicision was pawned in the bank so, with an increasing tukin they are like to get vitamins to increase stamina or enthusiasm so"

\section{Human Resourses}

An organization needs the support from human resources. Therefore, an organization needs to provide support for human resources. Thus, there will be a feeling of interrelation between the organization and human resources. Human resources organizations feel that the organization in which they work is an organization that cares them and is the best place to work, because they feel attached to the organization and are unfit to leave it. This situation shows that human resources have a commitment to the organization. The Ternate Commission Secretariat's resources are very limited but from the 
results of the interviews they are able to carry out the job assigned by the leader, it stated by respondent "HN" as follow:

"we can see the ability ... based on their work ... able to record absences and it is done every month"

The same was expressed by respondent"ARH" below:

" Until now there is not a significant problem, the fact that every month the tukin is paid on time. Then we still pay attention to those rules and up to now, yes ..."

The resource factor is one of the determinants of the successful implementation of the performance allowance policy. Although in terms of the number of managers of performance allowances are limited but by the ability, the employee is able to complete the work.

\section{The Commitment of implementing the policy}

The attitude of implementing the policy is a very important factor related to the implementation in a public policy. The most important characteristics owned by implementers are honesty, commitment, and democracy. The implementers who are highly committed and honest will always survive among the obstacles encountered in policy. Honesty drives the the implementator to keep the direction of based on program/policy guidelines. His/her commitment and honesty brought him/her to more enthusiasm in doing the steps of program consistently. A democratic attitude will increase the impression of both the implementator and the policy in front of the target group members. The commitment of the executors of this performance allowance policy is illustrated from the following statement from respondent "DD" below:

"for me I am not burdensome, yes ... so I just follow what has become the rule in this tukin"

A similar statement expressed by an respondent "NA" stated that:

"Well, we have to take responsibility because they we have already paid"

Based on the statement above, it can be generally described that the tendency of implementer in the implementating of the performance allowance policy has been going well. Employees who receive performance allowance have attitudes or perspectives that support the policy so that the process of implementing the performance allowance policy is effective.

\section{Obstacle factors in implementing of the Performance Allowance Policy}

Besides supporting factors, there are also hider factors to the implementation of providing performance allowance policy at Ternate Election Commission Secretariat, including:

\section{The Employees do not set an Employee Performance Goal at the beginning of the year}


154 | Jurnal Ilmiah Ilmu Administrasi Publik: Jurnal Pemikiran dan Penelitian Administrasi Publik Volume 9 Number 2, July- December 2019. Page 137-158

Based on the Decree of the Secretary General of the Election Commission No. 935 / SDM.07-Kpt / 05 / SJ / XII / 2017 Regarding to the Technical Guidelines for the Implementation of Performance Allowance at the General Election Commission Secretariat basis for calculating performance besides the attendance of course also the performance of employees. The employee's performance is stated in the performance goals must be prepared at the beginning of the year and assessed by leader directly as the main jobs and function of the employee for a year and of course as a basis for evaluating employee performance in calculating performance allowance payments. But in reality the new employees compile their respective performance goals in the middle or end of the year when the work is in progress. This was revealed from interviews with respondent "BMIA" as follow:

"Ideally, they should have made it at the beginning of the year, but in reality, in the middle there was even a new year end. The obstacle I don't understand why? But it leader and HRD are likely know only, but I am trying to convey them that the performance goals must be made at the beginning of the year. Nahl, these employees are also confused about what their job title is? Some of them have already know their jobs and functions, but some of them do not know yet. "

A similar opinion was expressed by respondent "HN" below:

"yaa ... if the problem is the employee's target obligation ... because If he/she wants to know a performance he/she makes sure by him/herself recapitulated of the results of performance. It means that if the payment based on the performance of employees in $t$ one year, employee must have a full month recap the results of his performance. Now it is because of coinciding with the election stage it's very busy so it is only made at the end of the year"

Based on the technical guidelines that have been determined, performance allowance received by employees are determined based on performance achievements measured by 2 (two) elements, which include performance appraisal ( 40\%) and employee attendance (60\%). But in reality from the statement above so far the TernateCommission paid performance allowances to employees based on attendance. This is due to the assessment of work performance still awaiting technical guidance from the Secretary General RI.

\section{Lack of facilities and infrastructure}

The lack of facilities and infrastructure is one of the factors hampering the implementation of the policy of providing performance allowance to the Ternate Election Commission Secretariat. One of the facilities and infrastructure in managing performance allowanve is the use of electronic attendance records or finger print. This was revealed from interviews with respondent "DD" as follow:

" the finger print is it just the first time. Now the machine is broken, so we just do it manually ... the signature is always on the attendance list "

The same statement stated by respondent"SMS" below: 
" there was a finger print a long time ago, but for one reason or another it was broken we are now in manual attendance list."

Based on the explanation from the respondents, it was revealed that Ternate Election Commission Secretariat was still using manual attendance recording despite the General Election Commission Decree No. 53 / Kpts / Setjen / 2016 concerning to Technical Guidelines for Implementing Performance Allowance at the General Election Commission, it stipulates that the use of an electronic attendance registration machine must be carried out starting from June 2016, this is justified by respondent "ARH":

"Ternate Election Commission has received assistance from the Ternate City Government to buy the equipment and it was able to use it until a few months later but for the time being it was damaged haha ... (laughs) and it has not been repaired, we are temporarily returning to the manual list. Now this is interesting because in terms of equipment related to tukin it needs to be increased including the costs for the pepairing itself. We have equipment, but maintenance is not provided by the budget, so if it is damaged, then we have to wait for it to be repaired ... like this time .. "

The same was expression stated by respondent "CNR" that:

"..Because our finger print attendance machine is in trouble so go back to the first time. The employees are free to come at any time but later write the absence according to the time of entering the office"

The use of recording attendance manually will cause in the lack of supervision and not transparancy in the processing of calculating the performance allowance so that the process of implementing the policy of granting performance allowance does not run as determined by the policy maker.

\section{Lack of Budget}

The lack of a budget is also an obstacle in the implementation of the performance allowance policy, this was revealed from the results of an interview with respondent "ARH" below:

"... Problem in the implementation of the tukin policy, first, related to regulations of the tukin, the socialization needs to be reproduced to improve the performance of the management of the tukin so that from the center commission to the distric / city have the same understanding related to the technical guidelines of the tukin, so that it does not have multiple interpretations, let alone circulating new technical guidelines yea ... especially from the provincial commission which is often invited by the center commission to take the bimtek when returning here it must be conveyed to the ranks of the commission below it. Second, in terms of budget, before there was a minus the tukin budget but after it is proposed now for the Ternate commission there is no problem in the payment of the tukin but there is an increase this year we will count again. In terms of equipment related to tukin it needs to be increased including the 
156 | Jurnal Ilmiah Ilmu Administrasi Publik: Jurnal Pemikiran dan Penelitian Administrasi Publik Volume 9 Number 2, July- December 2019. Page 137-158

cost for the maintenance itself. We have the equipment but the maintenance is not provided with the budget so if it breaks then we have to wait again to be repaired "

From the explanation above it can be concluded besides the lack of budget for employee performance allowance, there is also no budget for equipment and machine maintenance, especially for electronic finger print machines, there is not honorarium for the performance allowance manager, it explained by the respondent" ARH "the below:

"Well ... that is the stipulation, there must be an official then in the decree, but then there is not the decree, if not mistaken, there is no honorarium, so the decree is n't made haha ... (laughs)"

The budget for the performance allowance is very important for the smooth process of managing the performance allowance, so it is good planning is needed so that it does not become an obstacle in the implementation of the performance allowance policy.

\section{CONCLUSION}

The implementation of the policy on the provision of employee performance allowance at Ternate General Election Commission related to communication, resources, disposition, and bureaucratic structures has been running well but they are not maximally, therefore it causes several deviations the management of performance allowances. The supporting factors for the implementation are: 1) The increasing performance allowance is a motivation factor in appreciating of the commitment of employees in completing their job well. With this increasing performance allowance, employees increase their performance, 2) Human resources (HR), is a factor that can help the implementation of the performance allowance policy, because the increase human resource basis on their competencies will guarantee the realization of the rules that have been set, and 3) The Commitment of implementing the policy, the performance allowance recipient employees who have attitudes or perspectives that support the policy will realize the process of implementing the policy of providing performance benefits effectively. Factors which become obstacles in the implementation of implementation are: 1) Employees do not set up Employee Performance goals at the beginning of the year which are the basis for calculating performance allowance besides employees' attendance, 2) Lack of facilities and infrastructure, in this case is the list of electronic attendance records or finger print, and 3) The lack of a performance allowance budget is one of the factors that hinders the process of implementing the performance allowance policy because it will affect the process of disbursing the performance allowance expenditure.

\section{REFERENCES}

Akib, H., \& Salam, R. (2016). Analisis Kualitas Pelayanan Publik Berbasis Importance Performance Analysis (IPA) pada Kecamatan Kota Makassar. Jurnal Ilmiah Scientific Pinisi, 2(April 2016), 16-20.

Blatt, B., Bogdan, R., Biklen, D., \& Taylor, S. (1977). From institution to community: A 
Eko Ady Prabowo, et all.; The Implementation of Providing Performance Allowance Policy... | 157

conversion model. Educational Programming for the Severely and Profoundly Handicapped, 40-52.

Creswell, J. W., \& Poth, C. N. (2018). Qualitative inquiry Research Design Choosing Among Five Approaches (Vol. 53). https://doi.org/10.1017/CBO9781107415324.004

Dessler, G. (1999). How to earn your employees' commitment. Academy of Management Perspectives, 13(2), 58-67.

Dhaliwal, I., \& Hanna, R. (2017). The devil is in the details: The successes and limitations of bureaucratic reform in India. Journal of Development Economics, 124, 1-21. https://doi.org/https://doi.org/10.1016/j.jdeveco.2016.08.008

Johnsen, H. (2015). Professional responses to post bureaucratic hospital reforms and their impact on care provision. Women and Birth, 28(2), e19-e25. https://doi.org/https://doi.org/10.1016/j.wombi.2015.01.006

Mathwich, N., \& Pavao-Zuckerman, B. (2018). Bureaucratic reforms on the frontier: Zooarchaeological and historical perspectives on the 1767 Jesuit Expulsion in the Pimería Alta. Journal of Anthropological Archaeology, 52, 156-166. https://doi.org/https://doi.org/10.1016/j.jaa.2018.07.002

Pratiwi, N. J., Jamaluddin, J., Niswaty, R., \& Salam, R. (2019). The Influence of Work Facilities on Employee Performance at the Regional Financial Management Agency Secretariat Section of South Sulawesi Province. Jurnal Ad'ministrare, 6(1), 35-44.

Saggaf, M. S., Aras, M., Akib, H., Salam, R., Baharuddin, A., \& Kasmita, M. (2018). The Quality Analysis of Academic Services Based on Importance Performance Analysis (IPA).

Shet, S. V, Patil, S. V, \& Chandawarkar, M. R. (2019). Competency based superior performance and organizational effectiveness. International Journal of Productivity and Performance Management, 68(4), 753-773. https://doi.org/10.1108/IJPPM-03-2018-0128

Widodo, D. S. (2014). Influence of leadership and work environment to job satisfaction and impact to employee performance (Study on Industrial manufacture in West Java). Journal of Economics and Sustainable Development, 5(26), 2010-2015.

Wihantoro, Y., Lowe, A., Cooper, S., \& Manochin, M. (2015). Bureaucratic reform in postAsian Crisis Indonesia: The Directorate General of Tax. Critical Perspectives on Accounting, 31, 44-63. https://doi.org/https://doi.org/10.1016/j.cpa.2015.04.002

Wilfahrt, M. (2018). The politics of local government performance: Elite cohesion and crossvillage constraints in decentralized Senegal. World Development, 103, 149-161. https://doi.org/https://doi.org/10.1016/j.worlddev.2017.09.010 
158 | Jurnal Ilmiah Ilmu Administrasi Publik: Jurnal Pemikiran dan Penelitian Administrasi Publik Volume 9 Number 2, July- December 2019. Page 137-158 